\title{
KAJIAN STRUKTUR ANATOMI DAN MORFOLOGI DAUN PLANLET PISANG KEPOK KUNING HASIL PEMBERIAN EKSTRAK UMBI KEMBANG SUNGSANG SECARA IN VITRO
}

Yoga Aji Saputra ${ }^{1 *}$, Eti Ernawiati², Rochmah Agustrina ${ }^{3}$, Sri Wahyuningsih ${ }^{4}$

1,2,3,4Universitas Lampung, Jl. Prof. Dr. Ir. Sumantri Brojonegoro, Kota Bandar Lampung, Lampung 35141, Indonesia

*Corresponding author, e-mail: saputrayogaaji1@gmail.com

\begin{abstract}
Plantain is a fruit commodity that has a high level of market demand, but the yield is low. To overcome this problem, tissue culture techniques are used to increase plantlet production in a short time. Plantain have parthenocarpy character, high sterility, and different levels of ploidy. Tissue culture with the addition of flame lily tuber biomutagen containing colchicine was used as a strategy to overcome the above constraints because it was thought to increase the production of polyploid banana plantlets. Changes in the anatomical and morphological structures are indicators of polyploidy. The purpose of this study was to obtain information on changes in the anatomical and morphological structures of plantain leaves as a result of giving in vitro plantlet propagation media as an indicator of the formation of polyploidy. Plantlets were grown on tissue culture media supplemented with three treatments: $10 \%$ flame lily tuber extract, $0.1 \%$ pure colchicine, and without addition (control). The parameters observed were epidermal cell size, stomata size, stomata index, number and leaf area. Epidermal cell size, stomata size and stomatal index were analyzed using range values and mean values. The number of leaves, and the average wide of leaf, is then shown in the form of a bar chart. The results showed that administration of flame lily tuber extract was able to increase epidermal cell size, stomata size, wide of a leaf, and able to reduce the stomata index and number of leaves.
\end{abstract}

Keywords: Flame lily tubers extract, Pantain, Polyploid, Tissue culture

\section{PENDAHULUAN}

Pisang banyak disukai oleh masyarakat Indonesia dari berbagai kalangan, baik dari kalangan bawah hingga kalangan atas dan salah satu komoditas buah unggulan Indonesia (Wibowo et al., 2010). Luas panen dan produksi pisang selalu menempati posisi pertama. Pisang merupakan buah yang mengandung gizi tinggi, mudah didapat dan harganya terjangkau, sebagai sumber vitamin, mineral dan juga karbohidrat. kandungan nutrisi pada pisang antara lain mineral, karbohidrat, serat dan vitamin A, B, C (Ambarita, 2015) dapat membantu memperlancar sistem metabolisme tubuh, meningkatkan daya tanah tubuh dari radial bebas. Serta menjaga kondisi tetap kenyang dalam waktu lama (Wijaya, 2013).

Salah satu jenis pisang yang sangat digemari masyarakat adalah pisang kepok (Musa paradisiaca L.). Pisang kepok merupakan salah satu jenis pisang lokal Indonesia hasil persilangan Musa acuminata dan Musa balbisiana (Simmonds \& Shepherd, 1995). Pisang kepok ini memiliki 2 jenis yaitu pisang putih dan pisang kepok kuning. Permintaan pasar terhadap pisang kepok kuning relatif tinggi, karena jenis pisang ini banyak digunakan sebagai bahan olahan makanan tradisional maupun 
industri rumahan seperti selai, keripik, tepung pisang, dan sale pisang. Permintaan terhadap pisang kepok kuning yang tinggi tidak diimbangi dengan tingkat produksi yang memadai. Rendahnya produksi pisang kepok kuning diduga karena budidaya pisang yang tidak tepat. Dengan demikian diperlukan sebuah terobosan bioteknologi untuk memperoleh kultivar pisang kepok unggul, salah satunya dengan teknik pemuliaan mutasi.

Mutasi dapat dilakukan dengan cara menambahkan senyawa tertentu yang dapat menyebabkan terjadinya mutasi atau disebut mutagen. Kolkisin diketahui dapat dijadikan sebagai salah satu mutagen. Namun kolkisin sintesis harganya relatif mahal. Solusi untuk memperoleh kolkisin alami yaitu dengan memanfaatkan kembang sungsang, karena kandungan senyawa kolkisinnya sangat tinggi dan mudah didapat. Kembang sungsang diketahui mengandung senyawa kolkisin pada seluruh organnya. Selain itu, seluruh bagian dari tanaman ini mengandung senyawa aktif, misalnya pada umbi diketahui mengandung alkaloid yang sangat toksit, yaitu kolkisin sekitar 0,1-0,8 \%, pada batang 0,33-0,41\% (Jana \& Shekhawat, 2011). Menurut Suminah et al. (2005), kolkisin mampu mencegah terbentuknya benang spindel pada sel yang aktif membelah karena mampu berikatan dengan tubulin, protein penyusun utama mikrotubul. Oleh karena itu kembang sungsang berpotensi menjadi biomutagen.

Senyawa kolkisin ini juga sering digunakan untuk menginduksi mutasi (poliploid). Senyawa ini mampu menghentikan pembelahan sel (antimitosis), yaitu dengan cara menghambat pembentukan benang gelendong sehingga sel tidak dapat ditarik ke kutub berlawanan dan kromosom menyebar dalam sel, pembentukan membran sel baru terhambat dan akhirnya membentuk sel dengan jumlah kromosom meningkat atau bersifat poliploid. Berdasarkan hal tersebut, maka perlu diketahui struktur anatomi dan morfologi daun planlet pisang kepok kuning hasil pemberian ekstrak umbi kembang sungsang secara in vitro.

\section{METODE}

\section{Waktu dan Tempat Penelitian}

Penelitian ini dilaksanakan dari Mei-Juni 2020, penelitian ini dilakukan di Laboratorium Botani, Jurusan Biologi, Fakultas Matematika dan Ilmu Pengetahuan Alam, Universitas Lampung.

\section{Alat dan Bahan}

Alat-alat yang digunakan dalam penelitian ini yaitu pinset, botol larutan, beaker glass, gelas objek, gelas penutup, silet, mikroskop, gunting, neraca analitik, alat tulis dan kamera. Bahan-bahan yang digunakan yaitu daun planlet pisang kepok kuning yang diperoleh dari penelitian tahap 1 (induksi planlet pisang kepok kuning), alkohol, pewarna safranin $1 \%$ (dilarutkan dalam aquades), tissue, gliserin 10\%, pemutih pakaian, dan aquades.

\section{Rancangan}

Observasi terhadap daun planlet pisang kepok kuning hasil perlakuan media kontrol (A1), media diberi tambahan ekstrak umbi kembang sungsang $10 \%$ (A2) dan media diberi kolkisin 0,1 \% (A3). Pengamatan pada masing-masing perlakuan dilakukan pada 10 planlet pisang kepok kuning sebagai satuan pengulangan.

\section{Prosedur Kerja}

1. Preparasi anatomi daun

Daun dikerik hingga tipis, kemudian direndam dalam larutan pemutih pakaian selama 5 menit. Sisa klorofil dibersihkan dengan aquades. Kemudian sampel diwarnai 
dengan safranin 1\% dan ditaruh diatas gelas obyek dalam medium gliserin $10 \%$, kemudian ditutup dengan gelas penutup (Dorly, 1989). Preparat irisan membujur daun ini dibuat menggunakan permukaan bawah daun. Sediaan yang telah siap diamati dibawah mikroskop pada perbesaran $1000 \mathrm{X}$ (dibantu minyak emersi). Kemudian diambil gambarnya menggunakan kamera.

2. Pengamatan stomata, sel epidermis, dan indeks stomata daun

Pengukuran stomata dan sel epidermis dilakukan pada 15 kali untuk setiap ulangan. Sedangkan untuk indeks stomata (IS) dihitung pada 10 bidang pandang untuk tiap ulangan. Menurut Royer (2001), indeks stomata dapat di tentukan dengan menggunakan rumus :

Indeks Stomata $=\frac{\text { Jumlah Stomata }}{\text { Jumlah Stomata+Jumlah Sel Epidermis }} \times 100 \%$

3. Pengamatan jumlah daun planlet

Jumlah daun pisang dihitung dari hasil setiap perlakuan dan ulangan secara manual.

4. Pengamatan luas daun planlet

Perhitungan luas daun menggunakan metode gravimetri kertas. Kertas duplikat ukuran $10 \times 10 \mathrm{~cm}$ ditimbang. Kemudian daun planlet pisang digambar pada kertas menggunakan pensil, lalu replika daun pada kertas dipotong menggunakan gunting. Selanjutnya hasil potongan replika daun tersebut ditimbang menggunakan timbangan analitik. Menurut Irwan (2017), perhitungan luas daun planlet dapat menggunakan rumus sebagai berikut:

Luas Daun $=\frac{\text { Berat Replika Daun Planet }}{\text { Berat Kertas } 10 \mathrm{~cm} \times 10 \mathrm{~cm}} \times 100 \%$

\section{Analisis Data}

Parameter yang diamati dalam penelitian ini adalah ukuran sel epidermis, ukuran stomata, indeks stomata, jumlah daun, dan luas daun. Analisis data ukuran sel epidermis, ukuran stomata, dan indeks stomata dianalisis menggunakan nilai kisaran dan nilai rata-rata. Jumlah daun dan luas daun dirata-rata kemudian ditampilkan dalam bentuk diagram batang.

\section{HASIL DAN PEMBAHASAN}

Hasil pengamatan anatomi daun planlet pisang kepok kuning hasil perlakuan penamban ekstrak umbi kembang sungsang (A2), penambahan kolkisin (A3) dan kontrol (A1) dapat dilihat pada Tabel 1.

Tabel 1. Ukuran sel epidermis, stomata, dan indeks stomata (perbesaran $1000 \mathrm{x}$ )

\begin{tabular}{|c|c|c|c|c|c|c|c|}
\hline \multirow[t]{2}{*}{ Parameter } & & \multicolumn{2}{|l|}{ A1 } & \multicolumn{2}{|l|}{ A2 } & \multicolumn{2}{|l|}{ A3 } \\
\hline & & Kisaran & Rata-Rata & Kisaran & Rata-rata & Kisaran & Rata-rata \\
\hline \multirow[t]{2}{*}{ Sel Epidermis $(\mu \mathrm{m})$} & $\mathrm{P}$ & $25-78$ & $35,99 \pm 2,73$ & $25-62$ & $40,78 \pm 1,52$ & $26-69$ & $41,11 \pm 1,57$ \\
\hline & $\mathrm{L}$ & $10-28$ & $15,49 \pm 0,91$ & $10-28$ & $15,98 \pm 1,17$ & $10-26$ & $\pm 0,86$ \\
\hline \multirow[t]{2}{*}{ Stomata $(\mu \mathrm{m})$} & $\mathrm{P}$ & $24-35$ & $28,23 \pm 0,74$ & $19-35$ & $28,81 \pm 1,52$ & $25-35$ & $29,68 \pm 0,98$ \\
\hline & $\mathrm{L}$ & $12-26$ & $17,08 \pm 0,7$ & $11-27$ & $18,08 \pm 1,62$ & $15-25$ & $19,95 \pm 0,43$ \\
\hline Indeks Stomata (\%) & & $0-10,2$ & $3,13 \pm 0,62$ & $0-9,8$ & $3,02 \pm 1,08$ & $0-9,09$ & $2,99 \pm 1,14$ \\
\hline
\end{tabular}

Sel epidermis daun planlet pisang kepok kuning dari media yang diberi perlakuan penambahan ekstrak umbi kembang sungsang 10\% (A2) dan kolkisin 0,1\% (A3) lebih panjang dibandingkan planlet dari media kontrol (A1). Namun untuk lebar, ketiga perlakuan menunjukkan nilai rata-rata lebar yang hampir sama (Tabel 1). 
Peningkatan ukuran panjang sel epidermis daun planlet pisang kepok kuning diduga karena telah terbentuk planlet pisang kepok kuning poliploid. Dugaan ini sesuai dengan hasil penelitan Ernawiati et al. (2014) yang melaporkan terjadinya peningkatan ukuran sel epidermis cabai merah akibat perendaman benih cabai dengan pemberian ekstrak biji kembang sungsang 0,025\%.

Ukuran panjang dan lebar stomata pada daun planlet dari perlakuan penambahan ekstrak umbi kembang sungsang 10\% (A2) sedikit lebih besar jika dibandingkan perlakuan kontrol (A1). Panjang dan lebar stomata daun planlet dari perlakuan penambahan kolkisin 0,1\% (A3) menunjukkan ukuran yang paling besar (Tabel 1). Penambahan ekstrak umbi kembang sungsang 10\% (A2) pada media mampu menaikkan ukuran stomata jika dibandingkan dengan perlakuan pada media kontrol (A1), sehingga diduga telah terjadi poliploidi. Namun hasilnya lebih rendah dibandingkan dengan perlakuan penambahan kolkisin 0,1\% pada media (A3). Konsentrasi ekstrak mampu menaikkan ukuran stomata namun diduga belum optimal untuk memunculkan sel poliploid. Penambahan ukuran stomata tertinggi pada penelitian ini dijumpai pada perlakuan penambahan kolkisin $0,1 \%$ pada media (A3). Hasil ini dapat diduga telah terbentuk sel poliploid pada pisang kepok kuning. Hasil ini sesuai dengan hasil penelitian Rohmah et al. (2017) yang menunjukkan adanya peningkatan ukuran sel stomata daun zaitun akibat pemberian kolkisin 0,75 \%. Menurut Ernawati et al. (2010), kandungan kolkisin yang cukup besar ini dapat dimanfaatkan sebagai biomutagen yang sangat prosepktif dalam menghambat proses mitosis dan terbentuknya sel poliploid.

Indeks stomata pada perlakuan A2 nilainya lebih rendah dibandingkan A1. Namun pemberian kolkisin 0,1\% (A3) menunjukkan nilai yang paling rendah (Tabel 1). Indeks stomata berbanding terbalik dengan ukuran stomata. Semakin tinggi ukuran stomata maka nilai indeks stomata akan semakin rendah (Pharmawati \& Wistiani, 2015). Hal ini mengindikasikan penambahan ekstrak umbi kembang sungsang pada media tanam mampu menurunkan indeks stomata (IS).

Penurunan indeks stomata tersebut diduga telah terbentuk planlet pisang kepok kuning poliploid. Hal ini sejalan dengan penelitian Pharmawati dan Wistiani (2015) yang menyebutkan bahwa terjadi penurunan indeks stomata daun tanaman bawang putih kultivar kesuna bali pada berbagai konsentrasi. Nilai indeks stomata berkaitan dengan ukuran stomata. Ukuran stomata yang makin besar akan memiliki indeks stomata yang makin kecil. Sebaliknya, jika ukuran stomata makin kecil maka nilai indeks stomata makin besar.

Rata-rata jumlah daun planlet pisang kepok kuning pada media kontrol (A1) dan media ditambah kolkisin $0,1 \%$ (A3) menunjukkan nilai yang sama yaitu 1,5. Media yang ditambah ekstrak umbi kembang sungsang 10\% (A2) memiliki jumlah daun yang paling rendah yaitu 1 . Hal ini dikarenakan efek kolkisin yang menghambat pembelahan sel berbanding lurus dengan jumlah daun. Menurut Crowder (1997), kolkisin dapat menginduksi sel meristem yang menyebabkan terhambatnya pembentukan benang-benang spindel yang menyebabkan kromatid tidak dapat terpisah pada tahap anafase. Hal ini mengakibatkan terjadinya penggandaan kromosom tanpa pembentukan sel baru. Oleh karena tidak terbentuk sel baru maka jumlah daun planlet tidak akan meningkat.

Luas daun planlet hasil perlakuan media yang ditambah ekstrak umbi kembang sungsang $10 \%$ (A2) yaitu 2,27 cm menunjukkan kenaikan yang signifikan dibandingkan dengan media kontrol (A1) yaitu 1,99 cm. Kenaikan ini juga dialami oleh daun planlet dari perlakuan penambahan kolkisin 0,1\% (A3) yang menghasilkan 
planlet dengan luas daun tertinggi yaitu 2,38 $\mathrm{cm}$. Penambahan ukuran stomata dan ukuran epidermis hasil percobaan ini memiliki korelasi positif terhadap penambahan luas daun planlet. Hal tersebut mengindikasikan bahwa penambahan ekstrak umbi kembang sungsang pada pisang kepok kuning diduga menghasilkan planlet yang poliploid.

Hasil ini sejalan dengan penelitian Rahayu et al. (2013) yang menyebutkan bahwa pemberian kolkisin dengan konsentrasi dan lama perendaman yang berbeda memberikan pengaruh nyata pada luas daun tanaman sedap malam. Diperkuat oleh penelitian Rahman et al. (2017) yang melaporkan bahwa pemberian kolkisin pada tanaman oyong (Luffa acutangula L.) memberikan pengaruh nyata terhadap luas daun pada berbagai konsentrasi.

\section{SIMPULAN}

Berdasarkan penelitian yang telah dilakukan didapatkan kesimpulan penambahan ekstrak umbi kembang sungsang 10\% pada media kultur jaringan pisang kepok kuning mampu meningkatkan ukuran sel epidermis, stomata dan luas daun. Serta mampu menurunkan indeks stomata dan jumlah daun planlet pisang kepok kuning. Hasil tersebut menjadi indikator kuat terbentuknya planlet pisang kepok kuning yang poliploid.

\section{REFERENSI}

Ambarita M D Y., Bayu E S., Setiado H. (2015). Identifikasi Karakter Morfologis Pisang (Musa sp.) di Kabupaten Deli Serdang. Jurnal Agroekoteknologi 4 (1) :19111924.

Crowder, L.V. (1997). Genetika Tumbuhan. Diterjemahkan oleh Kusdiarti. UGM. Yogyakarta.

Dorly. (1989). Membandingkan Anatomi Daun Varietas Orba dan Muria. Laporan Masalah Khusus. IPB. Bogor.

Ernawiati, E., Destiliani, A., dan Yulianty. (2014). Profil Anatomi Daun Cabai Merah Keriting (Capsicum annum L.) Akibat Pemberian Ekstrak Air Biji Kembang Sungsang. Jurnal Ilmiah. 2 (1): 16-19.

Ernawiati, E., Wahyuningsih, S., dan Yulianty. (2010). Efek Biomutagen Terhadap Mitosis Sel Akar Kecambah Cabai Merah(Capsicum Annum L.): Prosiding Seminar Nasional, Lampung: Universitas Lampung.

Jana, S., \& Shekhawat, G.S. (2011). Critical review on medicinally potent plant species: Gloriosa superba L. Fitoterapia. 82 (3): 293-301.

Pharmawati, M., dan Wistiani, N.L.A.J. (2015). Induksi Mutasi Kromosom dengan Kolkisin Pada Bawang Putih (Allium sativum L.) Kultivar 'Kesuna Bali'. Universitas Udayana. Jurnal Bioslogos. 5 (1): 18-25

Rahayu, Y.S., Istiyono, K., Prasetyo dan Andrys, U.R. (2013). Pengaruh Penggunaan Kolkisin Terhadap Pertumbuhan Vegetatif Tanaman Sedap Malam (Polianthes tuberose L.) Di Dataran Medium. Universitas Malang. Malang.

Rahman, A.F., Nandariyah dan Parjanto. (2017). Keanekaragaman Pertumbuhan dan Hasil Tanaman Oyong (Luffa acutangula L.) pada Berbagai Konsentrasi Kolkhisin. Agrotech Res J. 1 (1): 1-6.

Rohmah, A., Rahayu, T., dan Hayari, A. (2017). Pengaruh Kolkisin terhadap Karakter Stomata Daun Zaitun (Olea europaea L.). Jurnal Ilmiah BIOSAINTROPIS. 2 (2): 10-17. 
Royer, D.L. (2001). Stomatal Density and Stomatal Index as Indicators of Paleomosperic CO2 Consentration. Review of Paleobotany and Palynology 114 (2001): 1-28.

Simmonds, N.W., and Shepherd, K. (1955). The taxonomy and origins of the cultivated bananas. Linnean Society. Botanical J. 55 (359): 302-312.

Wibowo A., Joko T., Subandiyah S. (2010). Increase Resistance Of Kepok Kuning Bananaagainst Blood Disease Through Somaclonal Variation And Endophytic Symbiosis. Jurnal Perlindungan Tanaman Indonesia, 16 (1): 15-21.

Wijaya, C.H. Noryawati M. (2013). Bahan Tambahan Pangan Pewarna. Bogor: IPB Press. 